\title{
Immunomodulatory effects of soluble CD5 on experimental tumor models
}

\author{
Inês T. Simões ${ }^{1}$, Fernando Aranda ${ }^{1}$, Esther Carreras ${ }^{1}$, Maria Velasco-de Andrés ${ }^{1}$, \\ Sergi Casadó-Llombart ${ }^{1}$, Vanesa G. Martinez ${ }^{1, *}$ and Francisco Lozano ${ }^{1,2,3, *}$ \\ 1mmunoreceptors of the Innate and Adaptive System, Institut d'Investigacions Biomèdiques August Pi i Sunyer, 08036,
Barcelona, Spain
${ }^{2}$ Servei d'Immunologia, Centre de Diagnòstic Biomèdic, Hospital Clínic de Barcelona, 08036, Barcelona, Spain
${ }^{3}$ Departament de Biomedicina, Facultat de Medicina, Universitat de Barcelona, 08036, Barcelona, Spain
${ }^{*}$ These authors share senior authorship \\ Correspondence to: Francisco Lozano, email: FLOZANO@clinic.ub.es
}

Keywords: CD5; immunotherapy; immune-checkpoint; T regulatory cells; NK cells

Received: May 24, $2017 \quad$ Accepted: September 13, $2017 \quad$ Published: November 20, 2017

Copyright: Simões et al. This is an open-access article distributed under the terms of the Creative Commons Attribution License 3.0 (CC BY 3.0), which permits unrestricted use, distribution, and reproduction in any medium, provided the original author and source are credited.

\section{ABSTRACT}

Modulation of antitumor immune responses by targeting immune checkpoint regulators has been proven successful in the treatment of many different tumors. Recent evidence shows that the lymphocyte receptor CD5 -a negative regulator of TCR-mediated signaling- may play a role in the anti-tumor immune response. To explore such an issue, we developed transgenic C57BL/ 6 mice expressing a soluble form of human CD5 (shCD5E $\mu \mathrm{Tg}$ ), putatively blocking CD5-mediated interactions ("decoy receptor" effect). Homozygous shCD5E $\mu \mathrm{Tg}$ mice showed reduced growth rates of tumor cells of melanoma (B16-F0) and thymoma (EG7-OVA) origin. Concomitantly, increased $\mathrm{CD4}^{+}$and $\mathrm{CD8}^{+} \mathrm{T}$ cell numbers, as well as reduced proportion of $\mathrm{CD}^{+} \mathrm{CD25}^{+} \mathrm{FoxP3}^{+}\left(\mathrm{T}_{\text {reg }}\right)$ cells were observed in tumor draining lymph nodes (TdLN). TdLN cell suspensions from tumor-bearing shCD5E $\mu \mathrm{Tg}$ mice showed increased both tumor specific and non-specific cytolitic activity. Moreover, subcutaneous peritumoral (p.t.) injection of recombinant shCD5 to wild-type (WT) mice slowed B16-F0 tumor growth, and reproduced the above mentioned TdLN cellular changes. Interestingly, lower intratumoral IL-6 levels -an inhibitor of Natural Killer (NK) cell cytotoxity- were observed in both transgenic and rshCD5-treated WT mice and the anti-tumor effect was abrogated by mAb-induced NK cell depletion. Taken together, the results further illustrate the putative regulatory role of CD5-mediated interactions in anti-tumor immune responses, which would be at least in part fostered by NK cells.

\section{INTRODUCTION}

Cancer immunotherapy has taken advantage of either potentiating or inhibiting several immune cell surface receptors that modulate the intensity of the immune response -the so-called immune checkpoint regulators. Impairing the function of immune checkpoint inhibitors enhances ongoing immune responses and helps the host immune system to more efficiently eradicate exogenous (e.g., infection) or endogenous (e.g., cancer) challenges.
CD5 is a lymphoid member of the scavenger receptor cysteine-rich (SRCR) superfamily [1], which is expressed by all $\mathrm{T}$ cells and a small subset of mature B cells (B1a) [2]. CD5 physically associates with the antigen-specific receptor complex present on $\mathrm{T}[3,4]$ and $\mathrm{B}$ [5] cells (TCR and BCR, respectively) and co-localizes with it at the center of the T-Antigen presenting cell (APC) immune synapse [6, 7]. While initially considered a co-stimulatory receptor, studies in knock-out mice $[8,9]$ unequivocally demonstrated the negative modulatory role of CD5 on TCR/BCR signaling. Accordingly, thymocytes 
and B1a cells from CD5-deficient mice are hyperresponsive to TCR and BCR cross-linking, resulting in higher proliferation, mobilization of intracellular calcium and phosphorylation of several signaling proteins $[8,9]$. Interestingly, $\mathrm{T}$ and $\mathrm{B}$ cell populations with regulatory functions ( $\mathrm{T}_{\text {reg }}$ and B10 cells, respectively) express high surface CD5 levels, which in turn might be important to their generation and/or function $[10,11]$. Indeed, CD5deficient mice display higher number of natural $\mathrm{T}_{\text {reg }}$ cells, although their suppressive activity is a matter of controversy $[12,13]$.

A number of studies have reported the putative involvement of CD5 in the modulation of antitumor responses, this including the effective treatment with a non-depleting anti-CD5 (Lyt-1) monoclonal antibody (mAb) [14], and the adaptation of human CD5 expression levels in tumor infiltrating lymphocytes (TILs) [15, 16]. Moreover, CD5-deficient mice engrafted with B16-F10 melanoma cells displayed slower tumor growth compared to wild-type (WT) C57BL/6 mice, which was associated with tumor infiltration by $\mathrm{T}$ cells exhibiting a more activated phenotype and enhanced antitumor effector functions [17]. Latest evidence also comes from human genetic studies showing that functionally relevant CD5 variants are of prognostic value in cancer patients undergoing melanoma or chronic lymphocytic leukemia $[18,19]$.

The ultimate nature of the CD5 ligand/s is still a controversial issue due to the lack of intergroup reproducibility of the proposed ones (CD72, framework region of $\mathrm{IgV}_{\mathrm{H}}, \mathrm{gp} 200$, gp40-80, gp150, CD5 itself or IL6) $[20,21]$ imposing some constraints in deciphering the ultimate physiological function/s of CD5. In an attempt to unveil the role played by the receptor-ligand interaction/s mediated by CD5 in lymphocyte physiology, our group took advantage of the existence of a soluble form of human CD5 (shCD5) and the interspecies conservation of the CD5-ligand interaction/s. As reported for other lymphocyte surface receptors [22], shCD5 is detected at low concentrations ( $\mathrm{pg} / \mathrm{mL}$ range) in the serum of normal individuals, resulting from proteolytic cleavage upon lymphocyte activation [23]. Accordingly, a transgenic mouse line constitutively expressing higher sustained serum levels (ng/mL range) of shCD5 (shCD5E $\mu \mathrm{Tg}$ ) was developed [24]. This circulating shCD5 form was expected to interact with the CD5 ligand/s, thus interfering with the receptor-ligand interactions (decoy receptor effect), and resulting in a functional knockdown of CD5. Preliminary analysis of heterozygous shCD5E $\mu$ Tg mice showed a decreased frequency of spleen $\mathrm{T}_{\text {reg }}$ and peritoneal IL-10 producing B-cell (B10) populations together with an increased proportion of spleen Natural Killer T cells (NKT) [24]. Concomitantly, such mice showed exacerbated forms of different experimental mouse models of autoimmune diseases (Collagen-Induced Arthritis and Experimental Autoimmune Encephalitis) as well as enhanced anti-tumor immune responses against B16 melanoma cells [24], thus supporting the importance of CD5 in the regulation of peripheral immune responses.

To further assess the potential of the CD5 lymphocyte receptor as a putative target of immunomodulation in cancer, we have pursued the analysis of the local anti-tumor response in homozygous shCD5E $\mu \mathrm{Tg}$ mice. These mice showed significantly slower tumor growth when challenged with isogenic tumor cell lines of different lineages (melanoma and lymphoma). The analysis of tumor draining lymph nodes (TdLNs) showed lymphocyte subset changes compatible with increased anti-tumor immune responses. Importantly, most of the observations made with shCD5E $\mu \mathrm{Tg}$ mice were reproduced by subcutaneous peritumoral (p.t.) injection of recombinant shCD5 (rshCD5) to tumor-challenged WT mice, thus excluding the possibility of transgenesis artifacts and strongly supporting the immunomodulatory properties of shCD5 in cancer.

\section{RESULTS}

\section{shCD5E $\mu \mathrm{Tg}$ mice display enhanced anti-tumoral responses to certain tumor types}

In accordance with previous results from heterozygous shCD5E $\mu \mathrm{Tg}$ mice [24], the homozygous mice kept under conventional housing conditions showed statistically significant reduced tumor growth rates and tumor weight when challenged with isogenic B16-F0 melanoma cells, as compared with non-transgenic (NonTg) controls (Figure 1A). Similar results were observed when the anti-tumor response of shCD5E $\mu \mathrm{Tg}$ mice was evaluated against EG7 lymphoma cells stably expressing ovalbumin (EG7-OVA) (Figure 1B). On the contrary, the tumor growth rates did not differ between shCD5E $\mu \mathrm{Tg}$ and NonTg mice when injected with RMA-S lymphoma cells (a major histocompatibility complex class I-deficient RMA variant) (Figure 1C), MCA-205 sarcoma cells (Figure 1D), and MC-38 colon carcinoma cells (data not shown). These results indicate that shCD5E $\mu \mathrm{Tg}$ mice exhibit an improved non-specific anti-tumor response, which is nevertheless restricted to certain tumor cell types.

\section{shCD5E $\mu \mathrm{Tg}$ mice display increased lymphoid cell numbers in TdLN}

Further characterization of the anti-tumor response was performed by comparing the lymphocyte subset composition of tumor draining (TdLN) and contra-lateral (cLN) lymph nodes in B16-F0-challenged shCD5E $\mu \mathrm{Tg}$ and NonTg mice. As shown by Figure 2A, TdLN but not $\mathrm{cLN}$ from shCD5E $\mu \mathrm{Tg}$ mice, showed a statistically significant increment in total cell numbers compared with NonTg controls. The increase was at the expense of both $\mathrm{CD}^{+}$and $\mathrm{CD}^{+}$total $\mathrm{T}$ cells (Figure $2 \mathrm{~B}$ and $2 \mathrm{C}$ ), 
but not of other lymphocyte subsets such as NK, NKT or B cells (Supplementary Figure 1). Regarding lymphocyte cell subset percentages, no significant differences were observed between shCD5E $\mu \mathrm{Tg}$ and NonTg controls; the only exception being $\mathrm{CD}^{+} \mathrm{T}$ cells, which were increased in TdLN from shCD5E $\mu \mathrm{Tg}$ mice (Figure 2C right). Worth noting was the fact that, although the percentage and number of total $\mathrm{CD}^{+} \mathrm{T}$ cells was increased in the TdLN of shCD5E $\mu \mathrm{Tg}$ mice, the percentage of $\mathrm{CD}^{+}$ cells with regulatory phenotype $\left(\mathrm{CD} 25^{+} \mathrm{FoxP}^{+}\right)$was found to be reduced in both TdLN and cLN compared to NonTg controls (Figure 2D). However, the suppressive activity of $\mathrm{T}_{\text {reg }}$ did not differ between shCD5E $\mu \mathrm{Tg}$ and NonTg controls (Supplementary Figure 2). Overall, the quantitative changes observed in $\mathrm{CD}^{+}, \mathrm{CD}^{+}$, and $\mathrm{T}_{\mathrm{reg}}$ T-cell subset composition of TdLN from shCD5E $\mu \mathrm{Tg}$ mice would be compatible with a more efficient anti-tumor response. It is worth mentioning on this regard, that similar TdLN changes were observed when shCD5E $\mu \mathrm{Tg}$ mice were challenged with tumor cells for which no efficient antitumor response was observed (namely, MCA-205) (Supplementary Figure 3). This would indicate that tumorrelated factors may be behind the inefficient anti-tumor response mounted by $\mathrm{shCD} 5 \mathrm{E} \mu \mathrm{Tg}$ mice against certain tumor cell types.

\section{shCD5E $\mu$ Tg mice exhibit enhanced tumor specific and unspecific cytotoxic responses}

To analyze the specificity of their anti-tumor immune responses, shCD5E $\mu \mathrm{Tg}$ and NonTg control mice were again challenged with EG7-OVA cells for
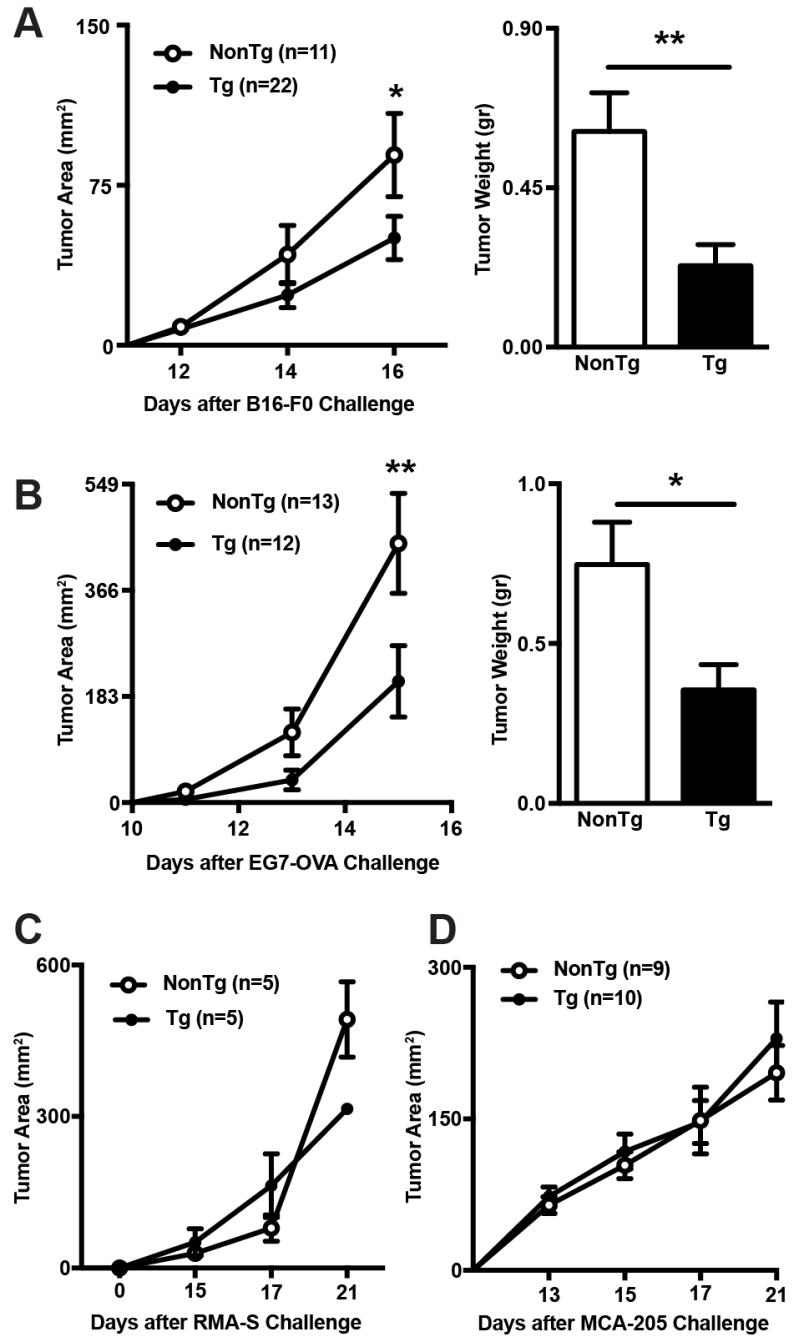

Figure 1: Comparison of tumor growth rates between shCD5E $\boldsymbol{\mu T g}$ and NonTg mice. (A) $\operatorname{shCD} 5 \mathrm{E} \boldsymbol{T} \mathrm{Tg}(\mathrm{n}=22)$ and NonTg mice $(\mathrm{n}=11)$ were injected s.c. with $5 \times 10^{4}$ B16-F0 melanoma cells and tumor area measured every other day (left panel). Tumor weight at day 16 is also represented (right panel). (B) Same as in A but injecting s.c. shCD5E $\mu \mathrm{Tg}(\mathrm{n}=12)$ and NonTg $(\mathrm{n}=13)$ mice with $5 \times 10^{4}$ EG7-OVA cells. (C) Tumor area curve from shCD5E $\mu \mathrm{Tg}$ mice $(\mathrm{n}=5)$ and NonTg $(\mathrm{n}=5)$ injected s.c. with $5 \times 10^{4} \mathrm{RMA}-\mathrm{S}$ cells. (D) Tumor area curve from $\operatorname{shCD} 5 \mathrm{E} \mu \mathrm{Tg}(\mathrm{n}=10)$ and $\operatorname{NonTg}(\mathrm{n}=9)$ mice injected s.c. with $5 \times 10^{4} \mathrm{MCA}-205$ cells. Values are represented as mean \pm SEM. " $\mathrm{p}<0.05 ;{ }^{* *} \mathrm{p}<0.01$ (unpaired $t$ test). 
further analyses of TdLN and cLN cell suspensions at the end of the follow-up period. As previously shown for B16-F0 cells, a statistically significant increase of total cells was observed in TdLN from EG7-OVA-challenged shCD5E $\mu \mathrm{Tg}$ mice (Figure 3A). The same LN cell suspensions were further cultured in vitro in the presence or absence of OVA-specific MHC class I-restricted SIINFEKL peptide or irradiated EG7-OVA cells. At $48 \mathrm{~h}$ post-stimulation, IFN- $\gamma$ production was assessed in culture supernatants by ELISA. As shown by Figure 3B, left panel, statistically significant higher levels of IFN- $\gamma$ were detected for TdLN cells from shCD5E $\mu \mathrm{Tg}$ mice under all the stimulatory conditions tested, compared with those of NonTg mice. The analysis of cLN cells from both mouse groups did not result in detectable IFN- $\gamma$ levels following stimulation (data not shown). Interestingly, similar IFN- $\gamma$ results were obtained when the same cLN and TdLN cell suspensions were challenged with irradiated allogeneic YAC-1 cells, a mouse thymoma of $\mathrm{A} / \mathrm{Sn}$ origin $(\mathrm{H} 2 \mathrm{a})$ commonly used for assaying NK-mediated cytotoxicity (Figure 3B, right panel). This would indicate that tumorchallenged shCD5E $\mu \mathrm{Tg}$ mice exhibit increased both specific and non-specific anti-tumor responses. Further evidence on the latter regard was obtained by performing lytic assays with spleen cell suspensions from EG7-OVAbearing shCD5E $\mu \mathrm{Tg}$ and NonTg mice. As illustrated by Figure 3C, shCD5E $\mu$ Tg mice bearing EG7-OVA tumors displayed significantly higher lytic activity not only against EG7-OVA cells (Figure 3C, left panel) but also RMA-S cells (Figure 3C, right panel).

\section{Exogenous administration of rshCD5 to WT mice induces similar TdLN changes to those observed in shCD5E $\mu$ Tg mice}

In order to exclude transgenesis artifacts and to get closer to a clinical application, the effects of rshCD5 infusion to WT mice bearing B16-F0 tumors was further
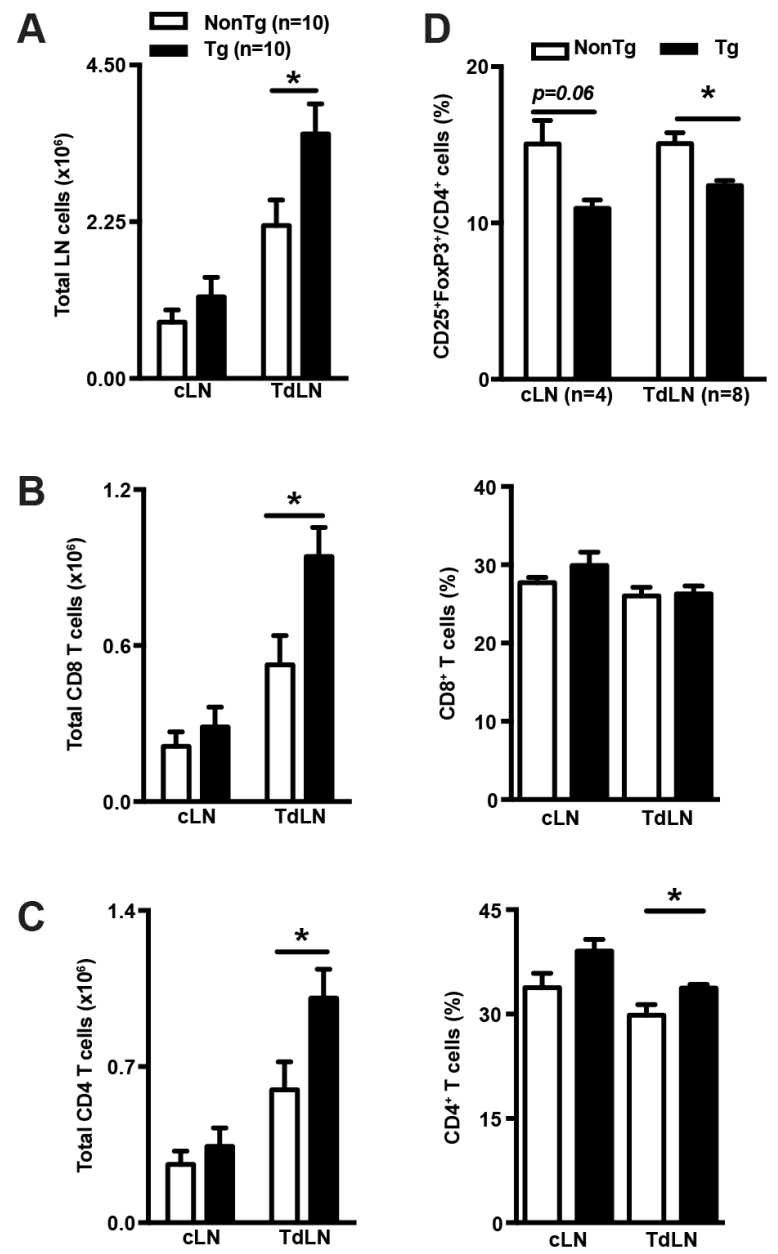

Figure 2: shCD5E $\mu$ Tg mice display increased lymphoid cell numbers in TdLN. (A) Total cell numbers from cLN and TdLN of shCD5E $\mu \mathrm{Tg}(\mathrm{n}=10)$ and NonTg $(\mathrm{n}=10)$ mice challenged with $5 \times 10^{4}$ B16-F0 cells were counted from single cell suspensions. (BC) Total numbers and percentage of $\mathrm{CD}^{+}(\mathrm{B})$ and $\mathrm{CD}^{+}(\mathrm{C}) \mathrm{T}$ cells from $\mathrm{cLN}$ and TdLN from the same mice as in A. (D) Percentage of $\mathrm{CD}_{25}{ }^{+} \mathrm{FoxP}^{+}$cells in $\mathrm{CD}^{+}$from cLN and TdLN of $\operatorname{shCD} 5 \mathrm{E} \mu \mathrm{Tg}(\mathrm{n}=8)$ and NonTg $(\mathrm{n}=8)$ mice challenged with B16-F0 cells. Values are represented as mean $\pm \mathrm{SEM}$ in a conventional mice facility. ${ }^{*} \mathrm{p}<0.05$ (unpaired $t$ test). 
explored. To this end, rshCD5 or human serum albumin (HSA) were administered every other day by two different routes (i.p. or p.t.) at two different doses (100 $\mu \mathrm{g}$ and 25 $\mu \mathrm{g})$ starting when tumors were $\sim 9-12 \mathrm{~mm}^{2}$ in size ( day 7-8). As illustrated by Figure 4A, peritumoral (p.t.) administration of high rshCD5 doses (100 $\mu \mathrm{g} / \mathrm{mice})$ induced a statistically significant slower tumor growth and lower tumor weight compared with those from HSA-treated mice. On the contrary, no significant effects on tumor growth were observed when rshCD5 was administered p.t. at low doses $(25 \mu \mathrm{g})$ or i.p. even at high doses $(100 \mu \mathrm{g})$ (Figure 4A). Significantly higher total cell numbers were observed in TdLN but not cLN cell suspensions from mice p.t. treated with rshCD5 $(100 \mu \mathrm{g})$ compared with HSA-treated ones (Figure 4B). The increment in total cell numbers from TdLN was at the expense of total $\mathrm{CD}^{+}$and $\mathrm{CD} 4^{+} \mathrm{T}$ cells as well as NK and NKT cell numbers (Figure 4C-4F). No statistically significant differences were observed regarding total B-cell numbers (Figure $4 \mathrm{G}$ ). The percentage of $\mathrm{CD}_{2} 5^{+} \mathrm{FoxP} 3^{+}$ cells within the $\mathrm{CD} 4^{+}$subset was significantly reduced in TdLN but not cLN from rshCD5-treated mice compared with HSA-treated ones (Figure $4 \mathrm{H}$ ). This finding was validated by the analysis of FoxP3 mRNA levels in TdLN from $p$.t. rshCD5-treated versus HSA-treated mice (Figure $4 \mathrm{H})$. Taken together, these results indicate that p.t. infusion of rshCD5 reproduces most of the observations made in shCD5E $\mu \mathrm{Tg}$ regarding slower tumor growth and cellularity changes in TdLN.

\section{Recombinant shCD5 impacts in $T_{\text {reg }}$ and $T_{H} 1$ in vitro polarization of naïve $T$ cells}

At this point, we decided to evaluate if shCD5 could interfere with the normal $\mathrm{T}_{\text {reg }}$ cell induction. To do
A

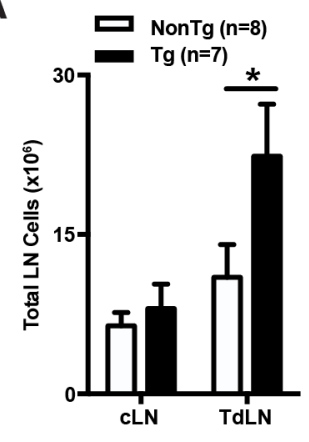

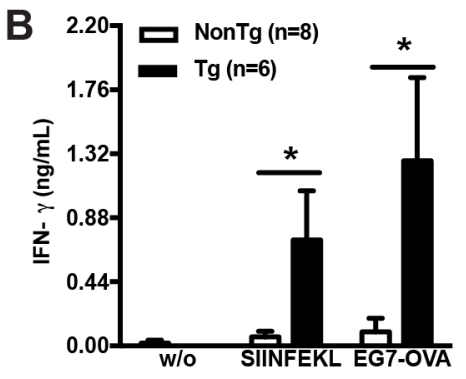

C

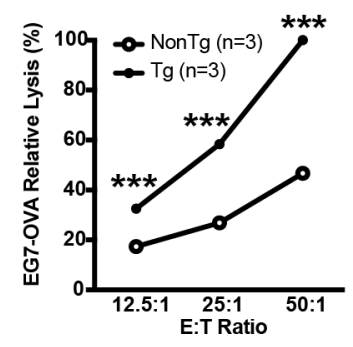

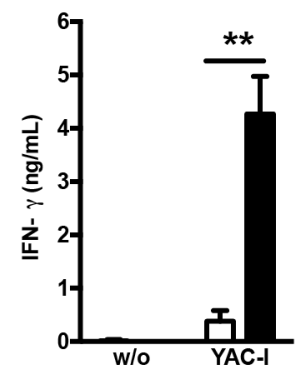

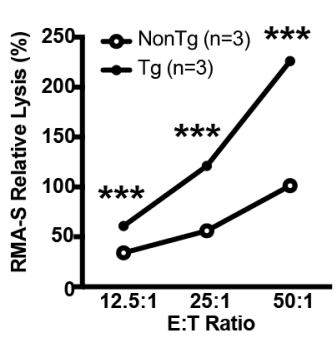

Figure 3: shCD5E $\mu \mathrm{Tg}$ mice exhibit enhanced innate and adaptive anti-tumor responses. (A) Total cell numbers from cLN and TdLN of shCD5E $\mu \mathrm{Tg}(\mathrm{n}=7)$ and NonTg $(\mathrm{n}=8)$ mice challenged with $5 \times 10^{4}$ EG7-OVA cells. (B) TdLN cells from the same mice as in A were co-cultured in the absence (w/o) or presence of SIINFEKL peptide, and irradiated EG7-OVA cells (left panel) or YAC-1 cells (right panel) for $48 \mathrm{~h}$. IFN- $\gamma$ levels $(\mathrm{ng} / \mathrm{ml})$ in culture supernatants are represented. Data are presented as mean \pm SEM. (C) Relative lysis of EG7OVA (left panel) and RMA-S (right panel) by LN cells from EG7-OVA tumor bearing mice. $5 \times 10^{4}$ irradiated tumor cells were co-cultured for $5 \mathrm{~h}$ at the indicated effector:target (E:T) ratios with pooled LN cells from shCD5E $\mu \mathrm{Tg}(\mathrm{n}=3)$ and NonTg $(\mathrm{n}=3)$ mice challenged with EG7-OVA cells for 15 days. Data are presented as mean \pm SEM from triplicates. ${ }^{*} \mathrm{p}<0.05 ;{ }^{* *} \mathrm{p}<0.01 ;{ }^{* * *} \mathrm{p}<0.0001$ (unpaired $t$ test). 
so in vitro polarization assays were performed with WT naïve T-cells. Under $\mathrm{T}_{\text {reg }}$ polarization conditions, $\mathrm{rshCD} 5$ induced a dose-dependent decrease in the percentage of $\mathrm{CD} 25^{+} \mathrm{FoxP}^{\text {hi }}$ cells (Figure $5 \mathrm{~A}$ ). This result is in

A
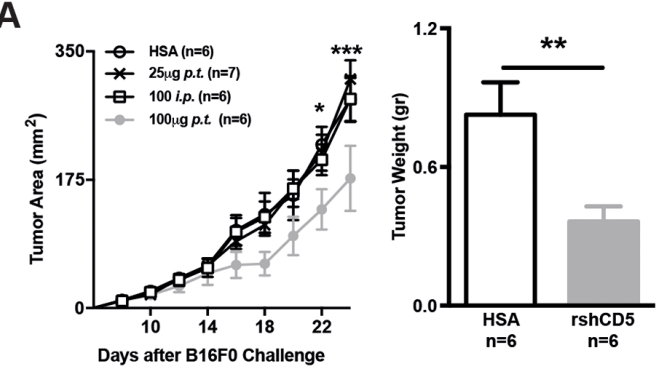

B

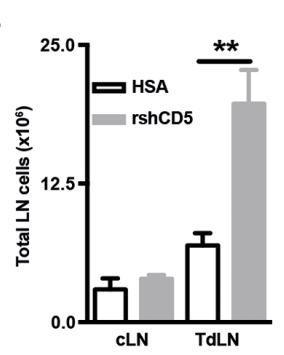

C

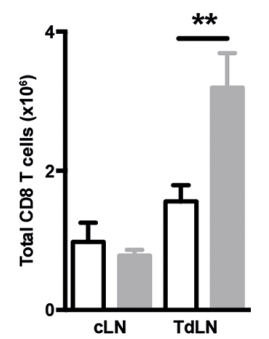

D

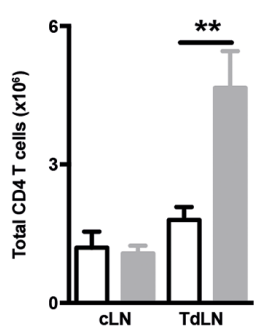

$\mathbf{F}$
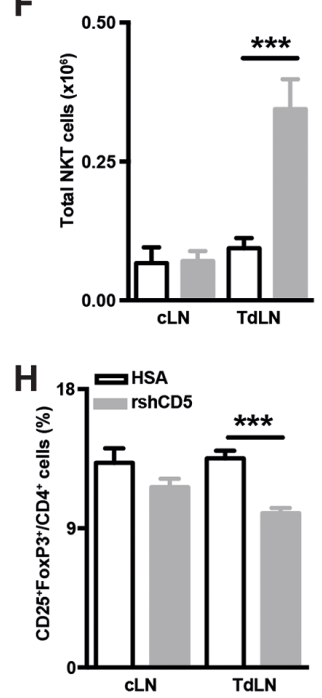

E

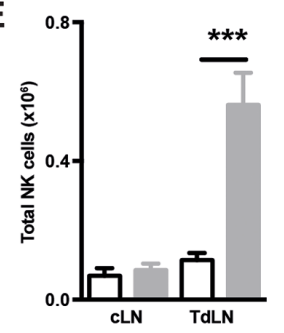

G
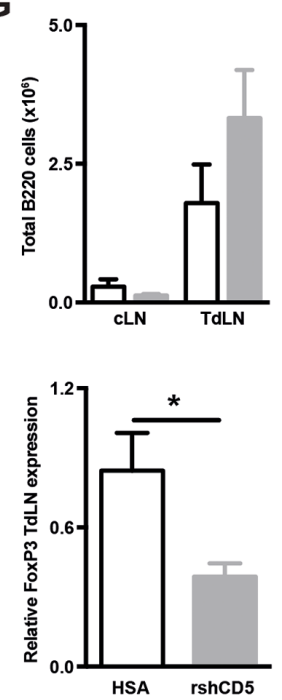

Figure 4: Exogenous administration of rshCD5 to WT mice mimics the anti-tumor effects of shCD5E $\mu$ Tg mice. (A) Tumor growth curve in HSA- and rshCD5-treated WT C57BL/6J mice ( $\mathrm{n}=6-7 /$ group) injected s.c. with $5 \times 10^{4} \mathrm{~B} 16$-F0 cells (left panel). HSA $\left(100 \mu \mathrm{g}\right.$ p.t.) or rshCD5 (25 or $100 \mu \mathrm{g}$, p.t. or i.p.) were administered every $48 \mathrm{~h}$ starting when tumor size was approx. $9-12 \mathrm{~mm}{ }^{2}(\sim$ day 7 post-injection). Tumor weight at day 23 is also represented (right panel). (B) Total cell numbers in cLN and TdLN from the same mice as in (A). (C-G) Total number of $\mathrm{CD}^{+}(\mathrm{C}), \mathrm{CD}^{+}(\mathrm{D})$ cells, NK (E), NKT (F) and B220 $(\mathrm{G})$ cells in cLN and TdLN from the same mice as in (A). (H) Percentage of $\mathrm{CD} 25^{+} \mathrm{FoxP}^{+}$cells in $\mathrm{CD}^{+}$from cLN and TdLN from the same mice as in A (left panel). The relative FoxP3 mRNA expression in TdLN cells from the same mice is represented (right). Data are presented as mean $\pm \mathrm{SEM} .{ }^{*} \mathrm{p}<0.05$, ${ }^{* *} \mathrm{p}<0.01$, and ${ }^{* * *} \mathrm{p}<0.0001$ (unpaired $t$ test). 
agreement with the lower percentage of $\mathrm{T}_{\text {reg }}$ cells observed both in the shCD5E $\mu \mathrm{Tg}$ and rshCD5-treated mice. On the other hand, when the same cells were polarized towards a $T_{H} 1$ phenotype, a trend towards increased proportion of $\mathrm{CD} 4^{+} \mathrm{IFN} \gamma^{+}$cells was observed in the presence of relative low rshCD5 concentrations $(0.1-1 \mu \mathrm{g} / \mathrm{mL})$, which reached statistical significance at $1 \mu \mathrm{g} / \mathrm{mL}$. Inconsistently, at higher rshCD5 concentrations ( 5 and $10 \mu \mathrm{g} / \mathrm{mL}$ ) no such enhancement effects were observed (Figure 5B). Although the bi-phasic effect of $\operatorname{rshCD} 5$ on $\mathrm{T}_{\mathrm{H}} 1$ polarization in vitro will require further elucidation, the more efficient $\mathrm{T}_{\mathrm{H}} 1$ polarization observed at low rshCD5 concentration (which are closer to the ones achieved in vivo) are also compatible with the enhanced anti-tumor response observed both in shCD5E $\mu \mathrm{Tg}$ and rshCD5-treated mice.

\section{NK cells are critical for the shCD5-induced anti- tumor effects}

The analysis of intratumor cytokine mRNA expression levels in B16-F0-challenged shCD5E $\mu \mathrm{Tg}$ and NonTg mice showed a trend to reduced IL- 6 but increased IL-15 mRNA levels, which only reached statistical significance in the former case. No significant differences were observed for other relevant cytokines (IFN- $\gamma$, IL-10, and IL-22) (Figure 6A, and data not shown). A similar result was obtained when rshCD5 was administrated exogenously (p.t.) to WT mice (Figure 6B). The fact that IL- 6 and IL-15 are inhibitor and activator, respectively, of NK effector functions [25, 26], together with the enhanced IFN- $\gamma$ release by TdLN cells from tumor-bearing shCD5E $\mu \mathrm{Tg}$ mice under both specific and non-specific re-stimulation conditions, prompted us

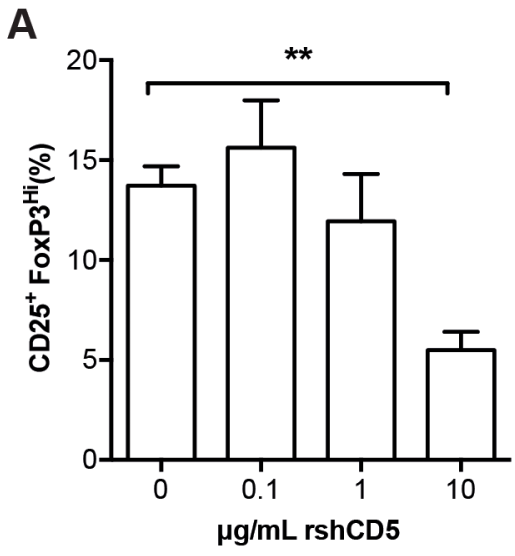

to confirm a putative implication of NK cells in the antitumor effects induced by transgenic or exogenous shCD5. To this end, shCD5E $\mu \mathrm{Tg}$ and Non-Tg mice were treated i.p. with an NK cell-depleting mAb (anti-NK1.1, clone PK136) or an isotype control every other day, starting with two consecutive doses two days before B16-F0 cells implantation. As illustrated by Figure 6C, NK celldepletion abrogated the statistically significant differences in tumor growth observed between shCD5E $\mu \mathrm{Tg}$ and NonTg mice treated with the isotype control antibody. Consistently, similar NK cell-depletion treatment also abrogated the enhanced anti-tumor effect of p.t. rshCD5 administration to tumor-bearing WT mice (Figure 6D), thus confirming the relevant role played by NK cells in shCD5-mediated outcome.

\section{DISCUSSION}

The present work further supports available evidence on the involvement of CD5 -a negative modulator of T-cell activation- in the fine-tuning of immune responses in general and of anti-tumor responses in particular [20, 27-29]. Our study shows that increasing the circulating/ local levels of a soluble form of human CD5 (shCD5) might result in both specific and non-specific enhancement of immune responses to cancer cells. This was achieved by using two different experimental approaches, one involving the use of a homozygous transgenic mouse line (shCD5E $\mu \mathrm{Tg}$ ) expressing circulating shCD5 [24], and the other involving repeated local infusions of purified recombinant shCD5 protein (rshCD5). Thanks to the interspecies recognition of the receptor-ligand interactions between mouse and human CD5 [24], functional blockade

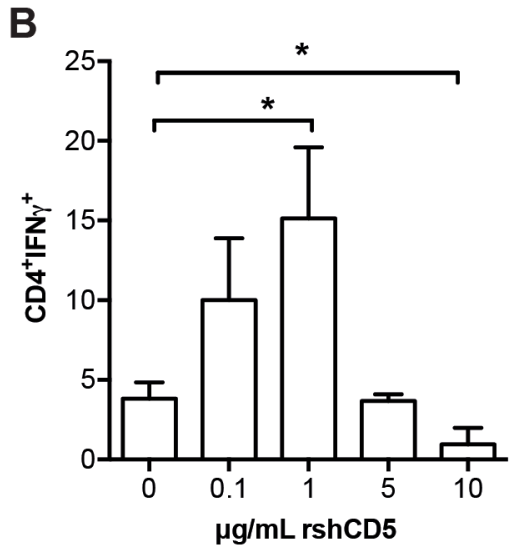

Figure 5: Effect of $\mathbf{r s h C D 5}$ on in vitro $\mathbf{T}_{\text {reg }}$ and $\mathbf{T}_{\mathbf{H}} \mathbf{1}$ polarization. Sorted naïve $\mathrm{T}$ cells $\mathrm{CD} 4^{+} \mathrm{CD} 25^{-} \mathrm{CD} 62 \mathrm{~L}^{\mathrm{hi}} \mathrm{CD} 44^{\text {lo }}$ cells $\left(1 \times 10^{5}\right)$ from C57BL/6 mice were activated for $96 \mathrm{~h}$ in triplicate with plate-bound $\alpha$-CD3 $(2 \mu \mathrm{g} / \mathrm{mL})$ and soluble $\alpha$-CD28 $\mathrm{mAb}(0.5 \mu \mathrm{g} / \mathrm{mL}) \mathrm{under}$ (A) $\mathrm{T}_{\text {reg }}$ polarization $(\alpha-\mathrm{IL}-4 \mathrm{mAb}, 1 \mu \mathrm{g} / \mathrm{mL}$; TGF- $\beta, 2 \mathrm{ng} / \mathrm{mL}$; IL-2, $5 \mathrm{ng} / \mathrm{mL}$; and of $\alpha$-IFN- $\gamma, 1 \mu \mathrm{g} / \mathrm{mL})$ or $(\mathbf{B}) \mathrm{T}_{\mathrm{H}} 1$ polarization $(\alpha-\mathrm{IL}-4$ $\mathrm{mAb}, 10 \mu \mathrm{g} / \mathrm{mL} ; \mathrm{IL}-2,5 \mathrm{ng} / \mathrm{mL}$; and IL-12, $10 \mathrm{ng} / \mathrm{mL})$ conditions in the presence of different amounts of rshCD5 $(0-10 \mu \mathrm{g} / \mathrm{mL})$. Then cells were (A) stained for surface CD4, CD25 and intracellular FoxP3 expression or (B) re-stimulated for 5 h with PMA (80 nM) and Ionomycin $(1 \mu \mathrm{g} / \mathrm{mL})$ in the presence of $2 \mu \mathrm{M}$ Monensin followed by surface CD4 and intracellular IFN- $\gamma$ staining, for further flow cytometry analyses. Data represent the mean percentage of double-positive cells $($ mean $\pm \mathrm{SD})$ from three experiments $(\mathrm{A})$ or one representative experiment of two (B) performed. ${ }^{*}, \mathrm{p}<0.05 ;^{* *}, \mathrm{p}<0.01$ (Unpaired $t$-test). 
of those interactions ("decoy receptor effect") is expected from both experimental approaches. Indeed, mouse and human CD5 are highly homologous receptors, with a gradient of amino acid homology from $60.2 \%$ for the
A
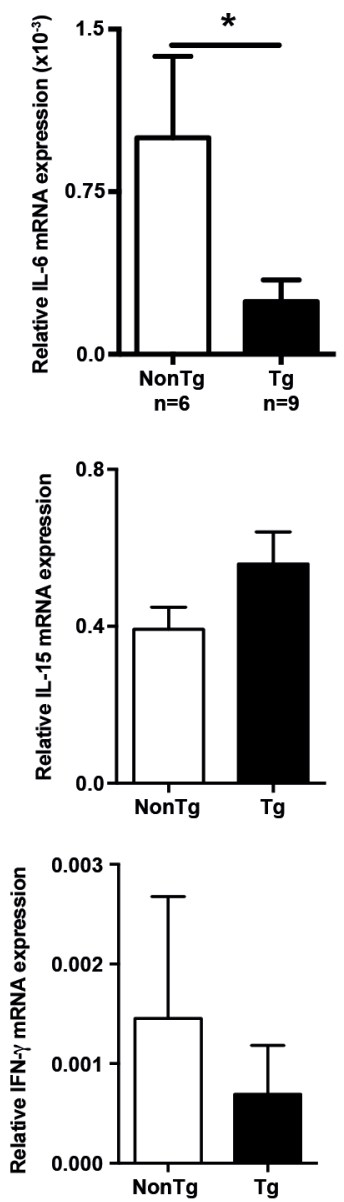

C $\square \mathrm{NonTg}+\alpha-\mathrm{NK} 1.1(\mathrm{n}=6)$ $* \mathrm{Tg}+\alpha-\mathrm{NK} 1.1(\mathrm{n}=8)$ $-\mathrm{Tg}+\mathrm{Iso}(\mathrm{n}=7)$

$\rightarrow$ NonTg + Iso $(n=3)$

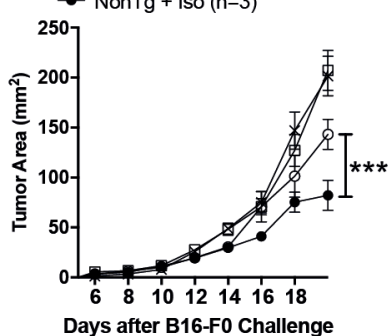

B
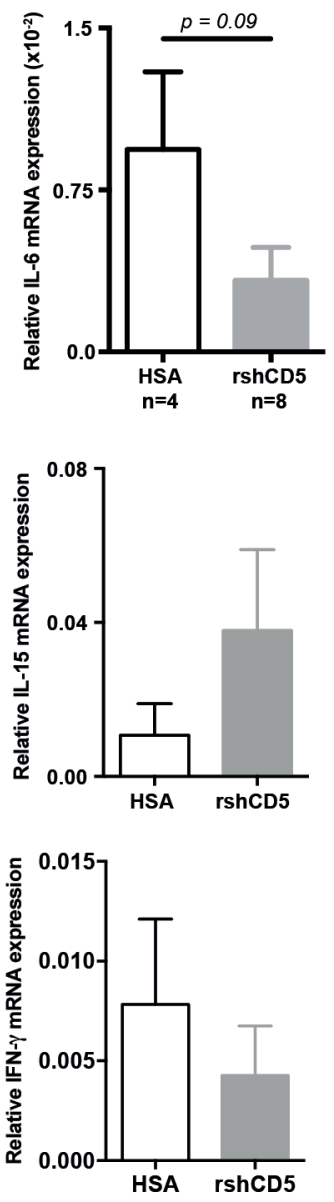

D

$$
\begin{aligned}
& -0-\text { HSA + Iso }(n=8) \\
& * \text { rshCD5 + } \alpha-N K 1.1(n=8) \\
& \rightarrow \text { rshCD5 + Iso }(n=8)
\end{aligned}
$$

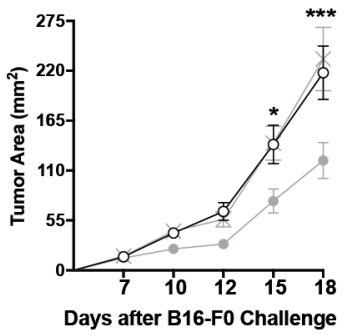

Figure 6: Abrogation of shCD5-mediated anti-tumor effects by NK cell depletion. (A) Relative IL-6 (top), IL-15 (middle) and IFN- $\gamma($ bottom) mRNA expression in tumors from shCD5E $\mu \mathrm{Tg}(\mathrm{n}=9)$ and NonTg mice $(\mathrm{n}=6)$ challenged with B16-F0 cells as in Figure 1A. Data are presented as mean \pm SEM. ${ }^{*} \mathrm{p}<0.05$ (unpaired $t$ test). (B) Relative IL-6 (top), IL-15 (middle) and IFN- $\gamma$ (bottom) mRNA expression in tumors from rshCD5- $(n=8)$ or HSA- $(n=4)$ treated WT mice challenged with B16-F0 cells as in Figure 4A. Data are presented as mean \pm SEM. (C) Tumor growth curves of shCD5E $\mu$ Tg and NonTg mice treated with anti-NK1.1-PK136 or IgG2a isotype control antibodies before and after challenge with $5 \times 10^{4}$ B16-F0 cells. (D) Tumor growth curves of B16-F0-challenged $\left(5 \times 10^{4}\right.$ cells) C57BL/6J mice treated with anti-NK1.1-PK136 or IgG2a isotype before and after starting administration of rshCD5 or HSA (100 $\mu$ g p.t.) when time tumor diameter was $\sim 9-12 \mathrm{~mm}^{2}$ ( day 7 post-injection). Data are presented as mean $\pm \mathrm{SEM}$. ${ }^{*} \mathrm{p}<0.05,{ }^{* * *} \mathrm{p}<0.0001$ (two-way ANOVA statistical test). 
N-terminal domain D1, 66.6\% for domain D2, $74.2 \%$ for domain D3 and $92.7 \%$ for the transmembrane and the C-terminal cytoplasmic region. Thus, the most conserved extracellular domain (D3) would be the most suited for interaction with putative CD5 ligand/s conserved interspecies. While minor amino acid sequence variation could deeply alter receptor function, it also true that amino acid positions important for protein structure and/ or function are relatively well conserved across species. This is well exemplified by the interaction of the closely related receptor CD6 with its ligand (CD166/ALCAM). The most membrane-proximal extracellular domain of human CD6 (D3) interacts with the most amino-terminal domain (D1) of human and mouse CD166/ALCAM and this is achieved through conserved key amino acids at the interaction interface [30].

Previous characterization of heterozygous shCD5E $\mu \mathrm{Tg}$ mice showed that they have significantly reduced proportions of spleen and lymph node $\mathrm{T}_{\text {reg }}$ cells $\left(\mathrm{CD}^{+} \mathrm{CD} 25^{+} \mathrm{FoxP}^{+}\right)$, and of peritoneal IL-10-producing $\mathrm{CD}^{+} \mathrm{B}$ (B10) cells, as well as increased proportions of spleen NKT cells [24]. Similar phenotypical changes were observed in WT mice following repeated i.p. administration of rshCD5 protein [24]. The functional relevance of these phenotypic changes was evidenced by delayed growth of B16-F0 melanoma tumors in shCD5E $\mu \mathrm{Tg}$ mice [24]. By using homozygous shCD5E $\mu \mathrm{Tg}$ mice, we show here that the enhanced antimelanoma response is not melanoma-specific since it also extends to cancer cells of lymphoid origin (namely, EG7 thymoma). However, no delayed tumor growth was observed for other cancer cells of different lineages (RMA-S lymphoma, MCA-205 sarcoma, and MC-38 colon carcinoma), thus indicating that differences in tumor antigenicity or other tumor-related factors should also be taken into consideration.

In an attempt to unravel the basis by which shCD5E $\mu \mathrm{Tg}$ mice displayed slower B16-F0 or EG7-OVA tumor growth, we found that their TdLNs had significant higher total cell numbers compared to NonTg controls. This included higher total numbers of $\mathrm{CD}^{+}$and $\mathrm{CD}^{+}$ $\mathrm{T}$ cells with lower percentage of $\mathrm{T}_{\mathrm{reg}}$ cells. The ex vivo re-stimulation of TdLN cells from EG7-OVA tumorbearing mice with SIINFEKL -a specific $\mathrm{CD}^{+} \mathrm{T}$ cell ovalbumin-derived peptide- showed that shCD5E $\mu \mathrm{Tg}$ mice were more responsive than NonTg controls, as deduced from increased IFN- $\gamma$ release. Interestingly, even higher IFN- $\gamma$ levels were observed when the same TdLN cells were re-stimulated with EG7-OVA cells or unrelated YAC-1 tumor cells. Concomitantly, stimulation of cLN cells rendered undetectable IFN- $\gamma$ levels. These results advocate for the existence of not only increased OVAspecific $\mathrm{CD}^{+}$-mediated responses in shCD5E $\mu \mathrm{Tg}$ mice, but increased unspecific anti-tumor responses as well. The fact that IFN- $\gamma$ levels following SIINFEKL stimulation were the lowest of all the stimuli tried allow speculating that $\mathrm{CD}^{+}$cells could represent only a minor source of IFN- $\gamma$. By contrast, the highest levels of IFN- $\gamma$ observed following stimulation with YAC-1 cells support a greater contribution of non-specific players such as NK cells. This indicates that the non-specific anti-tumor response is more relevant than the specific anti-tumor response in shCD5E $\mu \mathrm{Tg}$ mice after the tumor challenge.

The demonstration that the delayed tumor growth and the changes in TdLN composition observed in shCD5E $\mu \mathrm{Tg}$ mice were not transgenesis artifacts but the effect of shCD5 expression came from infusing WT mice with rshCD5 protein. Local (p.t.) treatment proved to be the most effective route, lowering tumor growth rate and weight in a dose-dependent manner. The presence of rshCD5 in the tumor environment was able to mimic the changes in TdLNs observed in shCD5E $\mu \mathrm{Tg}$ mice (increased total $\mathrm{CD}^{+}$and $\mathrm{CD}^{+}$T-cell numbers and decreased proportion of $\mathrm{T}_{\text {reg }}$ cells), but also to induce increased total NK and NKT cells - two cell types involved in non-specific anti-tumor responses. This scenario of increased specific and non-specific effector cells $\left(\mathrm{CD}^{+} \mathrm{T}\right.$, NK and NKT) and lowered regulatory cells $\left(\mathrm{T}_{\text {reg }}\right)$ would suit the observed anti-tumor effects. However, it should be taken into consideration that tumor-induced $\mathrm{T}_{\text {reg }}$ cells are known to differentially affect NK cells activated in the presence or absence of tumor cells [31].

An alternative or complementary scenario would relate to the detection of lower intratumor IL-6 mRNA levels in tumors from both shCD5E $\mu \mathrm{Tg}$ mice and rshCD5treated WT mice. IL-6 is a pro-inflammatory cytokine normally released by several cell types (e.g., monocytes, $\mathrm{T}$ cells, fibroblasts, epithelial and endothelial cells), and whose aberrant expression is associated with the growth, metastasis, and chemotherapeutic resistance in a wide range of cancers [32]. Inhibition of NK cell cytotoxicity by IL-6 has been reported in both mice and humans [25]. So, increased NK activity could be behind the observed exacerbated anti-tumor responses in transgenic and rshCD5-treated mice. This was supported by the fact that NK cell depletion in vivo fully reversed the beneficial effects of both transgenic and p.t. infused shCD5. This by no means totally excludes a putative contribution of other effector cells (namely $\mathrm{CD} 8^{+} \mathrm{T}$ cells).

Intriguingly, a recent report claims $\mathrm{CD} 5$ as a novel ligand for IL-6 [33]. The authors show that IL-6 activates STAT3 in $\mathrm{CD}^{+} \mathrm{B}$ cells in an IL-6 receptor-independent manner. This in turn promotes IL-10 expression and selfexpansion of regulatory $\mathrm{CD}^{+} \mathrm{CD} 19^{+} \mathrm{B}$ cells $(\mathrm{B} 10)$ in tumor microenvironment, resulting in promotion of tumor growth [33]. Based on this finding, it could be hypothesized that IL-6 sequestration by shCD5 would result in limiting the number and/or function of tumor-associated B10 cells. In this scenario, a blockade of IL-6-IL-6 receptor (IL6R) (membrane-bound or soluble) interaction [34] by the presence of shCD5 would limit any IL-6 activation positive feedback loop [33] resulting in low IL-6 mRNA levels. 
In conclusion, the data obtained from melanoma and thymoma tumor models support the notion that local/ systemic shCD5 would favor accumulation of innate and adaptive immune effector cells (by increased cell proliferation and/or cell recruitment) into TdLN, while limiting that of cells with regulatory function. This would be likely achieved by interfering (decoy receptor effect) with the interactions between CD5 and still illdefined membrane-bound and/or soluble ligand/s. There is, however, also the possibility that shCD5 effects could be mediated by decoying not only CD5 signaling but also that of other activator/suppressor cell surface receptors. Nevertheless, previous reports on CD5-deficient mice provide evidence that sole abrogation of CD5 signaling leads to enhanced anti-tumor response [17]. Our results with transgenic or exogenously infused rshCD5 are in full agreement with such evidence, and make unlikely the involvement of other receptors in the anti-tumor effects observed. Whatever the case, the results warrant future studies exploring CD5 targeting to improve the efficacy of currently available immunotherapeutic approaches against cancer such as IL-10 [35], TGF- $\beta$ inhibitors [36] or IL-2/ anti-IL-2 mAb immunocomplexes [37].

\section{MATERIALS AND METHODS}

\section{Tumor cell lines}

Melanoma B16-F0 cells were kindly provided by Dr. Ramón Alemany (Institut Català d'Oncologia, L'Hospitalet de Llobregat, Spain). RMA-S lymphoma cells were a kind gift from Dr. Pilar Lauzurica (Instituto de Salud Carlos III, Madrid, Spain). Thymoma EG7OVA cells were kindly provided by Dr. Elio Schouppe (Vrije Universiteit Brussel, Brussels, Belgium). Colon adenocarcinoma MC-38 cells and NK-sensitive YAC-1 cells were kindly provided by Dr. Pedro Berraondo and Dr. Pablo Sarobe (Center for Applied Medical Research, Pamplona, Spain). B16-F0 cells were grown in DMEM/ F12 (Gibco Life Science) supplemented with antibiotics (100 U/mL penicillin, $100 \mu \mathrm{g} / \mathrm{mL}$ streptomycin) and $10 \%$ heat-inactivated FBS (Walkersville). EG7-OVA, RMA-S, MCA-205, MC-38 and YAC-1 cells were grown in RPMI 1640 supplemented with antibiotics $(100 \mathrm{U} / \mathrm{mL}$ penicillin, $100 \mu \mathrm{g} / \mathrm{mL}$ streptomycin), $2 \mathrm{mM}$ L-glutamine, $10 \mathrm{mM}$ HEPES, $0.05 \mathrm{mM} \beta$-mercaptoethanol and $10 \%$ heatinactivated FBS.

\section{Mice}

In vivo studies were carried out at the animal facilities of the School of Medicine of the University of Barcelona under protocols approved by the Ethics Committee for Animal Research of the University of Barcelona (permits number 740/14, 741/14 and 54/16). Homozygous shCD5E $\mu \mathrm{Tg}$ transgenic mice of C57BL/6 genetic background were obtained by intercrossing of previously reported heterozygous mice [24]. The homozygosity of shCD5E $\mu \mathrm{Tg}$ mice was indirectly ascertained from their offspring breeding homozygous candidates with non-transgenic mice (NonTg). NonTg mice used for comparative purposes came from the same common heterozygous ancestors as the shCD5E $\mu \mathrm{Tg}$ mice and were kept under the same housing conditions as the latter. For some experiments WT C57BL/6J mice were purchased from Charles River. All animals were maintained under conventional (non-specific-pathogenfree) housing conditions.

\section{Recombinant proteins}

Production of purified rshCD5 protein (PBS with $10 \%$ glycerol, $\mathrm{pH} 7.4$ ) was carried out as previously reported [38] but using stable transfected SURE CHO-M Cell line ${ }^{\mathrm{TM}}$ clones from the Selexis SUREtechnology Platform ${ }^{\mathrm{TM}}$ (Geneva, Switzerland) and subjecting their serum-free supernatants to size-exclusion chromatography protocols developed at PX'Therapeutics (Grenoble, France). Recombinant Human Serum Albumin (HSA; in PBS with 10\% glycerol, pH 7.4) was from Sigma-Aldrich.

\section{Flow cytometry analysis}

The following mAbs were used to characterize mouse lymphocyte subpopulations: Fluorescein isothiocyanate (FITC)-labeled anti-CD4 (RM4-5, Tonbo Bioscience); Phycoerythrin (PE)-labeled anti-NK1.1 (PK136, BD Biosciences), anti-FoxP3 (FJK-16s), and anti-B220 (RA3-6B2, Tonbo Bioscience); PerCPCy5.5-labeled anti-CD3 (145-2C11, Tonbo Bioscience); Allophycocyanin (APC)-labeled anti-CD8 (53-6.7, Tonbo Bioscience) and anti-CD25 (PC61, BD Pharmingen); violetFluor 450-labeled anti-CD8 (53-6.7, Tonbo Bioscience). Before surface staining with predetermined optimal concentrations of each mAb, cell samples $\left(1 \times 10^{6}\right)$ were blocked by incubation with FBS $10 \%$ in PBS and anti-mouse CD16/CD32 (Fc Shield, 2.4G2, Tonbo Bioscience) for $30 \mathrm{~min}$ at $4^{\circ} \mathrm{C}$. For intracellular FoxP3 staining the PE-labeled anti-mouse/rat Treg Staining Kit (eBioscience) was used according to the manufacturer's instructions. Nine-color flow cytometry was performed on a BD FACSCanto II flow cytometer (Becton Dickinson, US) and data analyzed using FlowJo software (Tree Star, USA). Each analysis shown represents $\geq 100,000$ events within the live lymphocyte gate.

\section{$\mathbf{T}_{\text {reg }}$ suppression assay}

$\mathrm{CD}^{+} \mathrm{CD}^{-} 5^{-}\left(\mathrm{T}_{\text {conv }}\right)$ and $\mathrm{CD}^{+} \mathrm{CD}^{2} 5^{+}\left(\mathrm{T}_{\text {reg }}\right) \mathrm{T}$ cells were magnetically separated from LN specimens by autoMACS Pro Separator using the mouse CD4 ${ }^{+} \mathrm{CD} 25^{+}$ Regulatory $\mathrm{T}$ Cell Isolation Kit (Milteny Biotec). Upon CFSE-labeling, cells were co-cultured for $72 \mathrm{~h}$ at 2:1 
$\mathrm{T}_{\text {con }}: \mathrm{T}_{\text {reg }}$ ratio $\left(1 \times 10^{5}: 5 \times 10^{4}\right)$ in 96 -well $\mathrm{U}$-bottom plates pre-coated with $10 \mu \mathrm{g} / \mathrm{mL}$ anti-CD3 mAb (145.2C11; Tonbo Bioscience) or isotype control (Armenian hamster IgG isotype, BioLegend) plus $1 \mu \mathrm{g} / \mathrm{mL}$ soluble anti-CD28 (37.51; Tonbo Bioscience). $\mathrm{T}_{\text {conv }}$ cell proliferation was analysed by determining the percentage of $\mathrm{CFSE}^{\text {low }}$ cells in a BD FACSCanto II flow cytometer.

\section{In vivo tumor growth assays}

Mice were challenged by s.c. injection of B16-F0, EG7-OVA, RMA-S, MCA-205 or MC-38 cells $\left(5 \times 10^{4}\right)$ on the right flank with a 23-gauge needle. Tumors were measured every other day with a Vernier caliper, and the area (length by width of the tumors, $\mathrm{mm}^{2}$ ) averaged. For therapeutic assays, rshCD5 or HSA $(25 \mu \mathrm{g}$ or $100 \mu \mathrm{g}$ each per mouse) was administrated i.p. or p.t. every $48 \mathrm{~h}$, starting when tumors were $\sim 9-12 \mathrm{~mm}^{2}$ in size. In NK cell depletion experiments with shCD5E $\mu \mathrm{Tg}$ and NonTg mice, animals were i.p. administered with $200 \mu \mathrm{g}$ of NK1.1PK136 or rat $\mathrm{IgG}_{2 \mathrm{a}}$ isotype control (BioXCell) two days prior to tumor cell implantation. The following two days $100 \mu \mathrm{g}$ doses of the same antibodies were repeated. After this, $100 \mu \mathrm{g}$ doses were administered every $48 \mathrm{~h}$ until the end of the experiment. In the case of rshCD5- or HSAtreated WT mice, animals received $200 \mu \mathrm{g}$ i.p. of NK1.1PK136 or $\operatorname{IgG}_{2 \mathrm{a}}$ isotype control when tumors reached approximately $\sim 9-12 \mathrm{~mm}^{2}$. The following two days, a $100 \mu \mathrm{g}$ dose of the same antibodies was repeated. After this, $100 \mu \mathrm{g}$ doses were administered every $48 \mathrm{~h}$ until the end of the experiment, concurrently with rshCD5 or HSA protein administration.

\section{Cytotoxicity assays}

$\gamma$-irradiated ( 1 cycle of 2,000 rads) tumor cells were seeded at $5 \times 10^{4}$ cells/well in U-bottomed 96-well plates in RPMI 1640 supplemented with antibiotics but no FCS. Splenocytes obtained from tumor-bearing mice following tissue disaggregation through a cell strainer (Biologix group Ltd) and further red blood cell lysis (Red Blood cell lysis buffer; eBioscience) were then added at different effector:target (E:T) ratios and incubated for $5 \mathrm{~h}$. Tumor cell lysis was measured using the CytoTox-ONETM Homogeneous Membrane Integrity Assay (Promega) according to manufacturer's instructions and a microplate luminometry reader (Bio-TEK). Percentage of relative lysis was calculated as follows: $\%$ specific cytotoxicity $=$ [experimental lysis - spontaneous lysis]/[maximal lysis spontaneous lysis] $\times 100$.

\section{IFN- $\gamma$ measurement}

IFN- $\gamma$ levels in the cell culture supernatants were determined by BD OptEIA ${ }^{\mathrm{TM}}$ - Mouse ELISA Set (BD Biosciences) following manufacturer's instructions. To this end, TdLN or cLN cells $\left(2 \times 10^{5}\right)$ were co-cultured for
$48 \mathrm{~h}$ with EG7-OVA or YAC-1 irradiated cells $\left(2 \times 10^{4}\right)$ or OVA-specific SIINFEKL (5 $\mu$ g, Sigma) peptide at $37^{\circ} \mathrm{C}$ and $5 \% \mathrm{CO}_{2}$.

\section{Cytokine mRNA levels measurement}

Total RNA from tumor and LN samples was isolated by a TRIzol (Invitrogen)/chloroform (AnalaR NORMAPUR) procedure, and stored at $-80^{\circ} \mathrm{C}$ until use. Further purification of RNA was performed with the PureLink RNA Mini Kit (Ambion, Life technologies) according to manufacturer's instructions, and RNA purity assessed by the $260 / 280 \mathrm{~nm}$ ratio, with samples being studied only when ratio was between 1.8 and 2.2. Total cDNA was synthesized using the High capacity cDNA Reverse Transcription kit (Thermofisher) according to manufacturer's instructions. Samples were kept at $4^{\circ} \mathrm{C}$ (or $-20^{\circ} \mathrm{C}$ ) until quantitative real-time PCR (qPCR) performed. To this end, IL-6 (Mm01210733_m1), IL-10 (Mm01288386_m1), FoxP3 (Mm00475162_m1), IL15 (Mm00434210_m1) and IL-22 (Mm01226722_g1) specific Taqman probes and Taqman Fast universal PCR master Mix (Life Technologies/ThermoFisher) were used. Gene expression was determined by using $\mathrm{Ct}$ values inferior or equal to 30 cycles. The results were normalized with the expression values of the non-inducible gene Gliceraldehide-3-phosphate dehydrogenase (GADPH, Mm99999915_g1, Life Technologies/ThermoFisher), using the $2^{\Delta \overline{\mathrm{Ct}}}$ formula, where $\Delta \mathrm{Ct}=\mathrm{Ct}(\mathrm{GADPH})-\mathrm{Ct}$ (gene of interest). Results are represented as relative values.

\section{In vitro $T_{\text {reg }}$ and $T_{H} 1$ polarization of naïve $T$ cells}

FACS sorted (FACSAria) naïve $\mathrm{T} C D 4^{+} \mathrm{CD} 25^{-}$ CD62 $\mathrm{L}^{\text {hi }} \mathrm{CD} 44^{\text {lo }}$ cells $\left(1 \times 10^{5}\right)$ from $\mathrm{C} 57 \mathrm{BL} / 6$ mice were activated for $96 \mathrm{~h}$ in triplicate in 96-well U-bottom plates pre-coated $\alpha$-CD3 $(2 \mu \mathrm{g} / \mathrm{mL})$ and soluble $\alpha$-CD28 mAb $(0.5 \mu \mathrm{g} / \mathrm{mL})$ under $\mathrm{T}_{\text {reg }}$ polarization $(\alpha-\mathrm{IL}-4 \mathrm{mAb}, 1 \mu \mathrm{g} /$ $\mathrm{mL}$; TGF- $\beta, 2 \mathrm{ng} / \mathrm{mL}$; IL-2, $5 \mathrm{ng} / \mathrm{mL}$; and of $\alpha-\mathrm{IFN}-\gamma, 1$ $\mu \mathrm{g} / \mathrm{mL}$ ) or $\mathrm{T}_{\mathrm{H}} 1$ polarization $(\alpha-\mathrm{IL}-4 \mathrm{mAb}, 10 \mu \mathrm{g} / \mathrm{mL}$; IL-2, $5 \mathrm{ng} / \mathrm{mL}$; and IL-12, $10 \mathrm{ng} / \mathrm{mL}$ ) conditions in the presence of different amounts of rshCD5 (0-10 $\mu \mathrm{g} / \mathrm{mL})$. Cells were stained for surface CD4 and intracellular FoxP3 expression for $\mathrm{T}_{\text {reg }}$ analysis. For $\mathrm{T}_{\mathrm{H}} 1$ analysis, cells were re-stimulated for $5 \mathrm{~h}$ with PMA $(80 \mathrm{nM})$ and Ionomycin $(1 \mu \mathrm{g} / \mathrm{mL})$ in the presence of $2 \mu \mathrm{M}$ Monensin followed by surface CD4 and intracellular IFN- $\gamma$ staining, for further analyses with a BD FACSCanto II flow cytometer.

\section{Statistical analyses}

Statistical significance of differences between groups was determined using Student's $t$ test or ANOVA test, unless stated otherwise, using GraphPad Prism 5.03 software. In all experiments, differences were considered statistically significant when $p<0.05$. 


\section{Abbreviations}

rshCD5, recombinant soluble human CD5; nonTg, non-transgenic mice; cLN, contra-lateral lymph node; $\mathrm{TdLN}$, tumor draining lymph node; $\mathrm{mAb}$, monoclonal antibody; WT, wild type mice, p.t, subcutaneous peritumoral; i.p., intraperitoneal; $\mathrm{T}_{\mathrm{reg}}, \mathrm{T}$ regulatory cells; NK, Natural killer cells; NKT, Natural killer T cells; TCR, T-cell receptor; BCR, B-cell receptor.

\section{Author contributions}

IS performed most of the experiments, analyzed the data and wrote the manuscript. FA, EC and VM designed, performed and supervised the study and critically revised the manuscript. SC-L and MV-DA performed experiments. FL supervised the study, obtained funding, and wrote the manuscript.

\section{ACKNOWLEDGMENTS}

We are indebted to the Biobank and Cytomics core facilities of the IDIBAPS for their technical help. We thank Francisco Simões for graphics editing.

\section{CONFLICTS OF INTEREST} interests.

The authors declare no competing financial

\section{FUNDING}

This work is supported by grants from Worldwide Cancer Research (14-1275), Fundació La Marató TV3 (201319-30), and Spanish Ministerio de Economía y Competitividad (Plan Nacional I+D+i, SAF201346151-R and SAF2016-80535-R) -co-financed by European Development Regional Fund "A way to achieve Europe" ERDF. IS is recipient of a fellowship from Portuguese Fundação para a Ciência e a Tecnologia (SFRH/BD/75738/2011). FA holds a Sara Borrell fellowship (CD15/00016) from Instituto de Salud Carlos III. MV-DA and SC-L are supported by fellowships from the Spanish Ministerio de Economía y Competitividad (BES-2014-069237) and Ministerio de Educación, Cultura y Deporte (FPU15/02897), respectively.

\section{Ethical approval}

All applicable international, national, and/or institutional guidelines for the care and use of animals were followed. All procedures performed in studies involving animals were in accordance with the ethical standards of the institution or practice at which the studies were conducted.

\section{REFERENCES}

1. Martinez VG, Moestrup SK, Holmskov U, Mollenhauer J, Lozano F. The conserved scavenger receptor cysteine-rich superfamily in therapy and siagnosis. Pharmacol Rev. 2011; 63: 967-1000. https://doi.org/10.1124/pr.111.004523.

2. Berland R, Wortis $\mathrm{HH}$. Origins and functions of B-1 cells with notes on the role of CD5. Annu Rev Immunol. 2002; 20: 253-300. https://doi.org/10.1146/annurev. immunol.20.100301.064833.

3. Burgess KE, Yamamoto M, Prasad KV, Rudd CE. CD5 acts as a tyrosine kinase substrate within a receptor complex comprising T-cell receptor zeta chain/CD3 and proteintyrosine kinases p56lck and p59fyn. Proc Natl Acad Sci U S A. 1992; 89: 9311-5.

4. Beyers AD, Spruyt LL, Williams AF. Multimolecular associations of the T-cell antigen receptor. Trends Cell Biol. 1992; 2 : 253-5.

5. Lankester AC, van Schijndel GM, Cordell JL, van Noesel CJ, van Lier RA. CD5 is associated with the human B cell antigen receptor complex. Eur J Immunol. 1994; 24: 812-6. https://doi.org/10.1002/eji.1830240406.

6. Gimferrer I, Farnós M, Calvo M, Mittelbrunn M, Enrich C, Sánchez-Madrid F, Vives J, Lozano F. The accessory molecules CD5 and CD6 associate on the membrane of lymphoid T cells. J Biol Chem. 2003; 278: 8564-71. https:// doi.org/10.1074/jbc.M209591200.

7. Brossard C, Semichon M, Trautmann A, Bismuth G. CD5 inhibits signaling at the immunological synapse without impairing its formation. J Immunol. 2003; 170: 4623-9. https://doi.org/10.4049/jimmunol.170.9.4623.

8. Tarakhovsky A, Kanner S, Hombach J, Ledbetter J, Muller W, Killeen N, Rajewsky K. A role for CD5 in TCRmediated signal transduction and thymocyte selection. Science (80-). American Association for the Advancement of Science; 1995; 269: 535-7. https://doi.org/10.1126/ science. 7542801 .

9. Bikah G, Carey J, Ciallella JR, Tarakhovsky A, Bondada $\mathrm{S}$. CD5-mediated negative regulation of antigen receptorinduced growth signals in B-1 B cells. Science. 1996; 274: 1906-9. https://doi.org/10.1126/science.274.5294.1906.

10. Yanaba K, Bouaziz JD, Haas KM, Poe JC, Fujimoto M, Tedder TF. A regulatory $\mathrm{B}$ cell subset with a unique CD1dhiCD5+ phenotype controls $\mathrm{T}$ cell-dependent inflammatory responses. Immunity. 2008; 28: 639-50. https://doi.org/10.1016/j.immuni.2008.03.017.

11. Fehérvári Z, Sakaguchi S. A paragon of self-tolerance: CD25+CD4+ regulatory $T$ cells and the control of immune responses. Arthritis Res Ther. 2004; 6: 19-25. https://doi. org/10.1186/ar1037.

12. Dasu T, Qualls JE, Tuna H, Raman C, Cohen DA, Bondada $\mathrm{S}$. CD5 plays an inhibitory role in the suppressive function of murine CD4+ CD25+ Treg cells. Immunol Lett. 2008; 119: 103-13. https://doi.org/10.1016/j.imlet.2008.05.008. 
13. Ordoñez-Rueda D, Lozano F, Sarukhan A, Raman C, Garcia-Zepeda EA, Soldevila G. Increased numbers of thymic and peripheral CD4+ CD25+Foxp3+ cells in the absence of CD5 signaling. Eur J Immunol. 2009; 39: 2233 47. https://doi.org/10.1002/eji.200839053.

14. Hollander N. Immunotherapy of lymphoid and nonlymphoid tumors with monoclonal anti-Lyt-1 antibodies. J Immunol. 1984; 133: 2801-5.

15. Dorothée G, Vergnon I, El Hage F, Le Maux Chansac B, Ferrand V, Lécluse Y, Opolon P, Chouaib S, Bismuth G, Mami-Chouaib F. In situ sensory adaptation of tumorinfiltrating T lymphocytes to peptide-MHC levels elicits strong antitumor reactivity. J Immunol. 2005; 174: 6888-97.

16. Friedlein G, El Hage F, Vergnon I, Richon C, Saulnier P, Lecluse Y, Caignard A, Boumsell L, Bismuth G, Chouaib S, Mami-Chouaib F. Human CD5 protects circulating tumor antigen-specific CTL from tumor-mediated activationinduced cell death. J Immunol. 2007; 178: 6821-7. https:// doi.org/10.4049/jimmunol.178.11.6821.

17. Tabbekh M, Franciszkiewicz K, Haouas H, Lécluse Y, Benihoud K, Raman C, Mami-Chouaib F. Rescue of tumor-infiltrating lymphocytes from activation-induced cell death enhances the antitumor CTL response in CD5deficient mice. J Immunol. 2011; 187: 102-9. https://doi. org/10.4049/jimmunol.1004145.

18. Potrony M, Carreras E, Aranda F, Zimmer L, Puig-Butille JA, Tell-Martí G, Armiger N, Sucker A, Giménez-Xavier P, Martínez-Florensa M, Carrera C, Malvehy J, Schadendorf $\mathrm{D}$, et al. Inherited functional variants of the lymphocyte receptor CD5 influence melanoma survival. Int J cancer. 2016; 139: 1297-302. https://doi.org/10.1002/ijc.30184.

19. Delgado J, Bielig T, Bonet L, Carnero-Montoro E, Puente XS, Colomer D, Bosch E, Campo E, Lozano F. Impact of the functional $\mathrm{CD} 5$ polymorphism $\mathrm{A} 471 \mathrm{~V}$ on the response of chronic lymphocytic leukaemia to conventional chemotherapy regimens. Br J Haematol. 2016; 177: 147-50. https://doi.org/10.1111/bjh.14037.

20. Consuegra-Fernández M, Aranda F, Simões I, Orta M, Sarukhan A, Lozano F, Koplowitz E. CD5 as a target for immune-based therapies. Crit Rev Immunol. 2015; 35: 85-115.

21. Masuda K, Kishimoto T. CD5: a new partner for IL-6. Immunity. 2016; 44: 720-2. https://doi.org/10.1016/j. immuni.2016.03.011.

22. Bažil V. Physiological enzymatic cleavage of leukocyte membrane molecules. Immunol Today. 1995; 16: 135-40. https://doi.org/10.1016/0167-5699(95)80130-8.

23. Calvo J, Places L, Espinosa G, Padilla O, Vilà JM, Villamor N, Ingelmo M, Gallart T, Vives J, Font J, Lozano F. Identification of a natural soluble form of human CD5. Tissue Antigens. 1999; 54: 128-37. https://doi. org/10.1034/j.1399-0039.1999.540203.x.

24. Fenutría R, Martinez VG, Simões I, Postigo J, Gil V, Martínez-Florensa M, Sintes J, Naves R, Cashman KS,
Alberola-Ila J, Ramos-Casals M, Soldevila G, Raman C, et al. Transgenic expression of soluble human CD5 enhances experimentally-induced autoimmune and anti-tumoral immune responses. PLoS One. 2014; 9: e84895. https://doi. org/10.1371/journal.pone.0084895.

25. Cifaldi L, Prencipe G, Caiello I, Bracaglia C, Locatelli F, De Benedetti F, Strippoli R. Inhibition of natural killer cell cytotoxicity by interleukin-6: implications for the pathogenesis of macrophage activation syndrome. Arthritis Rheumatol (Hoboken, NJ). 2015; 67: 3037-46. https://doi. org/10.1002/art.39295.

26. Rautela J, Huntington ND. IL-15 signaling in NK cell cancer immunotherapy. Curr Opin Immunol. 2017; 44: 1-6. https://doi.org/10.1016/j.coi.2016.10.004.

27. Soldevila G, Raman C, Lozano F. The immunomodulatory properties of the CD5 lymphocyte receptor in health and disease. Curr Opin Immunol. 2011; 23: 310-8. https://doi. org/10.1016/j.coi.2011.03.003.

28. Tabbekh M, Mokrani-Hammani M, Bismuth G, MamiChouaib F. T-cell modulatory properties of CD5 and its role in antitumor immune responses. Oncoimmunology. 2013; 2: e22841. https://doi.org/10.4161/onci.22841.

29. Vasquez M, Simões I, Consuegra-Fernández M, Aranda F, Lozano F, Berraondo P. Exploiting scavenger receptors in cancer immunotherapy: lessons from CD5 and SR-B1. Eur J Immunol. 2017; 47: 1108-18. https://doi.org/10.1002/ eji.201646903.

30. Bowen MA, Bajorath J, D'egidio M, Whitney GS, Palmer D, Kobarg J, Starling GC, Siadak AW, Aruffo A. Characterization of mouse ALCAM (CD166): the CD6binding domain is conserved in different homologs and mediates cross-species binding. Eur J Immunol. 1997; 27 : 1469-78. https://doi.org/10.1002/eji.1830270625.

31. Pedroza-Pacheco I, Madrigal A, Saudemont A. Interaction between natural killer cells and regulatory $\mathrm{T}$ cells: perspectives for immunotherapy. Cell Mol Immunol. 2013; 10: 222-9. https://doi.org/10.1038/cmi.2013.2.

32. Liu Q, Yu S, Li A, Xu H, Han X, Wu K. Targeting interlukin-6 to relieve immunosuppression in tumor microenvironment. Tumor Biol. 2017; 39: 101042831771244. https://doi. org/10.1177/1010428317712445.

33. Zhang C, Xin H, Zhang W, Yazaki PJ, Zhang Z, Le K, Li W, Lee H, Kwak L, Forman S, Jove R, Yu H. CD5 binds to interleukin- 6 and induces a feed-forward loop with the transcription factor STAT3 in B cells to promote cancer. Immunity. 2016; 44: 913-23. https://doi.org/10.1016/j. immuni.2016.04.003.

34. Aparicio-Siegmund S, Deseke M, Lickert A, Garbers C. Trans-signaling of interleukin-6 (IL-6) is mediated by the soluble IL-6 receptor, but not by soluble CD5. Biochem Biophys Res Commun. 2017; 6: 1-5. https://doi. org/10.1016/j.bbrc.2017.01.174.

35. Dennis KL, Blatner NR, Gounari F, Khazaie K. Current status of interleukin-10 and regulatory T-cells in cancer. 
Curr Opin Oncol. 2013; 25: 637-45. https://doi.org/10.1097/ CCO.024855R1024855R10006.

36. Neuzillet C, Tijeras-Raballand A, Cohen R, Cros J, Faivre $\mathrm{S}$, Raymond E, De Gramont A. Targeting the TGF $\beta$ pathway for cancer therapy. Pharmacol Therapeut. 2015; 147: 22-31. https://doi.org/10.1016/j.pharmthera.2014.11.001.

37. Tomala J, Kovar M. IL-2/anti-IL-2 mAb immunocomplexes: a renascence of IL-2 in cancer immunotherapy?
Oncoimmunology. 2016; 5: e1102829. https://doi.org/10.1 080/2162402X.2015.1102829.

38. Sarrias MR, Padilla O, Monreal Y, Carrascal M, Abian J, Vives J, Yélamos J, Lozano F. Biochemical characterization of recombinant and circulating human Spalpha. Tissue Antigens. 2004; 63: 335-44. 